\title{
Vulvo-vaginitis in an adult with thread-worms in the vagina
}

\author{
P. P. KACKER \\ Royal Infirmary, Sheffield
}

\begin{abstract}
A 17-year-old, single, woman born in the United Kingdom attended on June 26, 1971, complaining of vaginal discharge and vulval soreness of 2 months' duration. There was no history of dysuria or of recent antibiotic treatment and she was not taking contraceptive pills. She had a British boy friend with whom she had regular intercourse; he was said to have no symptoms.
\end{abstract}

\section{General examination}

She was a healthy young woman with no clinical evidence of anaemia, clubbing of the nails, or palpable lymph nodes. No abnormal signs were found in the cardiovascular, respiratory, or gastrointestinal systems.

\section{Genital examination}

The vulva was red and covered with a whitish exudate; the vagina was slightly inflamed and four dead threadworms about $7 \mathrm{~mm}$. in length were found on the vaginal wall (Fig. 1). Swabs from the vulva and perianal region revealed the typical ova of Enterobius vermicularis (Fig. 2). Proctoscopy showed a normal anal canal and rectal mucosa.

\section{Laboratory investigations}

Haemoglobin $15 \cdot 2 \mathrm{~g}$. per cent.

White blood count 9,000; normal differential count.

Erythrocyte sedimentation rate $2 \mathrm{~mm}$./ Ist hr (Westergren).

Wassermann reaction and Kahn and Reiter protein complement-fixation tests were negative.

Scrapings from the finger-nails showed ova of Enterobius vermicularis with one typical flat side (Fig. 2).

Repeated urethral and cervical Gram-stained smears and cultures were negative for gonococci.

Repeated wet and dry films of vaginal secretion showed neither $T$. vaginalis nor the hyphae or spores of $C$. albicans.

The urine was clear and contained neither sugar nor albumin.

\section{Contacts}

Fresh stools from the patient's father, mother, and only brother showed no ova. The boy friend's stools likewise showed no ova but Giardia lamblia were demonstrated and a history of vague abdominal discomfort was elicited. His urine was normal.

\section{Treatment and follow-up}

The patient was treated with a single dose of 'Pripsen' $10 \mathrm{~g}$. (piperazine phosphate 4g.) with milk. Follow-up tests revealed no ova in stools, vulval swabs, finger-nail scrapings, or perianal specimens obtained by the sellotape/ slide method on three occasions.

The parents, brother, and boy friend were treated simultaneously with the same medication.

\section{Discussion}

Thread-worm infestation occurs by direct transfer or by ingestion of food or dust contaminated by ova. The patient and her boy friend had recently been on holiday in France, and for some months they had been in the habit ot eating regularly in Chinese restaurants, but whether these could be considered as sources of infestation was not clear. There appears to be a possibility in this case as no other members of the family were infested, though this was also the case with the patient's boy friend.

Infestation with Enterobius vermicularis is common in school children in whom it is a well-recognized cause of vulvo-vaginitis. All age groups are susceptible to bowel infestation, but clinically obvious vulvovaginitis with worms in the vagina in the adult is rare. How the vulva and vagina came to be so heavily infested in this case is not clear.

\section{Summary}

A case is reported of Enterobius vermicularis infestation causing vulvo-vaginitis in an adult. Investigations of the patient's family and boy friend failed to reveal thread-worms, but the patient was heavily infested with worms in the vagina. Treatment and follow-up are outlined.

The case is reported to remind clinicians of this rare cause of vaginal discharge and vulval discomfort in the adult. 

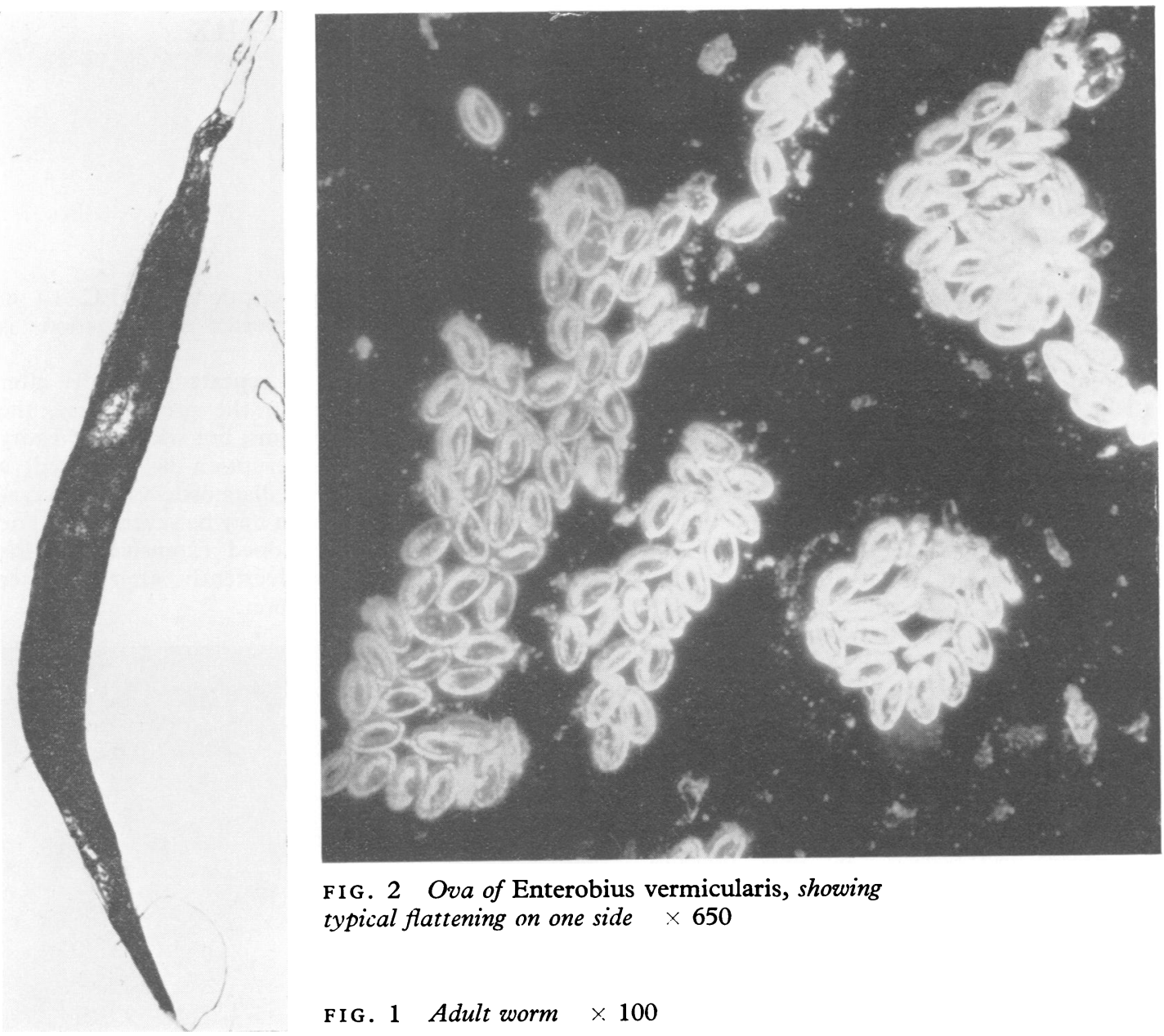

FIG. 2 Ova of Enterobius vermicularis, showing typical flattening on one side $\times 650$

FIG. 1 Adult worm $\times 100$

\section{Vulvo-vaginite chez un adulte avec présence d'oxyures dans le vagin}

\section{SOMMAIRE}

On rapporte le cas d'une infestation par Enterobius vermicularis ayant entrainé une vulvo-vaginite chez un adulte. Des recherches, chez la malade, dans sa famille et chez son partenaire ne réussirent pas à trouver d'oxyures mais le vagin de la malade était fortement infesté de vers. On indique le traitement et la surveillance.

Ce cas est publié pour rappeler aux cliniciens cette cause rare de leucorrhée et d'inconfort vulvaire chez l'adulte. 